\title{
Awabakal voices: The life and work of Percy Haslam
}

\author{
John Maynard
}

The late Percy Haslam, a noted journalist and scholar of Newcastle, had a long, continued and significant association with Aboriginal peoples within the Newcastle and Hunter Valley regions. The language, culture and history of the Awabakal became his obsession and life's work. Haslam died some 25 years ago and dozens of boxes of his papers and work were deposited with the archive section at the Auchmuty Library of the University of Newcastle. In 2001, with funding from an Australian Research Council (ARC) Indigenous Research Development Scheme Grant I set out to not only examine the works of Haslam but also reveal an understanding of the man behind the material. In saying that, I am not attempting a theoretical analysis of Haslam's work here but rather I offer an introductory biographical overview of the man by those that knew him intimately in the hope of stimulating further questions for research. Who was he? Where did he come from? What drove his insatiable interest in Aboriginal culture in particular the Awabakal? Purist and professional academics do tend to denigrate amateur ethnographers - where does this situate Haslam, his work and legacy?

Aboriginal community directive was very much at the forefront of my undertaking this study. Much respected, Newcastle Aboriginal elder, the late Uncle Bob Smith asked at an opening address of a Cultural Education symposium held at the University of Newcastle in 1998, 'Why doesn't someone do something with the works of Percy Haslam? It is tragic to think that this man's life work was wasted.' Ray Kelly, the then Director of the Awabakal Newcastle Aboriginal Coop Ltd, indicated his support. He said that Percy's work in its raw and unedited state was of little use to the local community. If however, it was edited and produced in a comprehensive published state it could prove to be of invaluable assistance in aiding greater understanding and appreciation of local Aboriginal history and culture to both Indigenous and non-Indigenous advantage. I was fortunate as a young boy that I grew up knowing not just Percy Haslam but also his brothers Ben and Harold (Doc) Haslam. Ben and Doc in particular were constant and regular visitors to our family home. Later I recall sitting on a seat at Broadmeadow racecourse in my early twenties and studying the form-guide with Percy who was a keen punter. It was only later, that I sadly realised not just of opportunities lost, but also of the importance of Percy's work. Today his memory and work is little remembered and this is the real tragedy. Percy Haslam was trying to leave a record and path for others to follow; hopefully his record can be restored to its rightful and deserved place. 


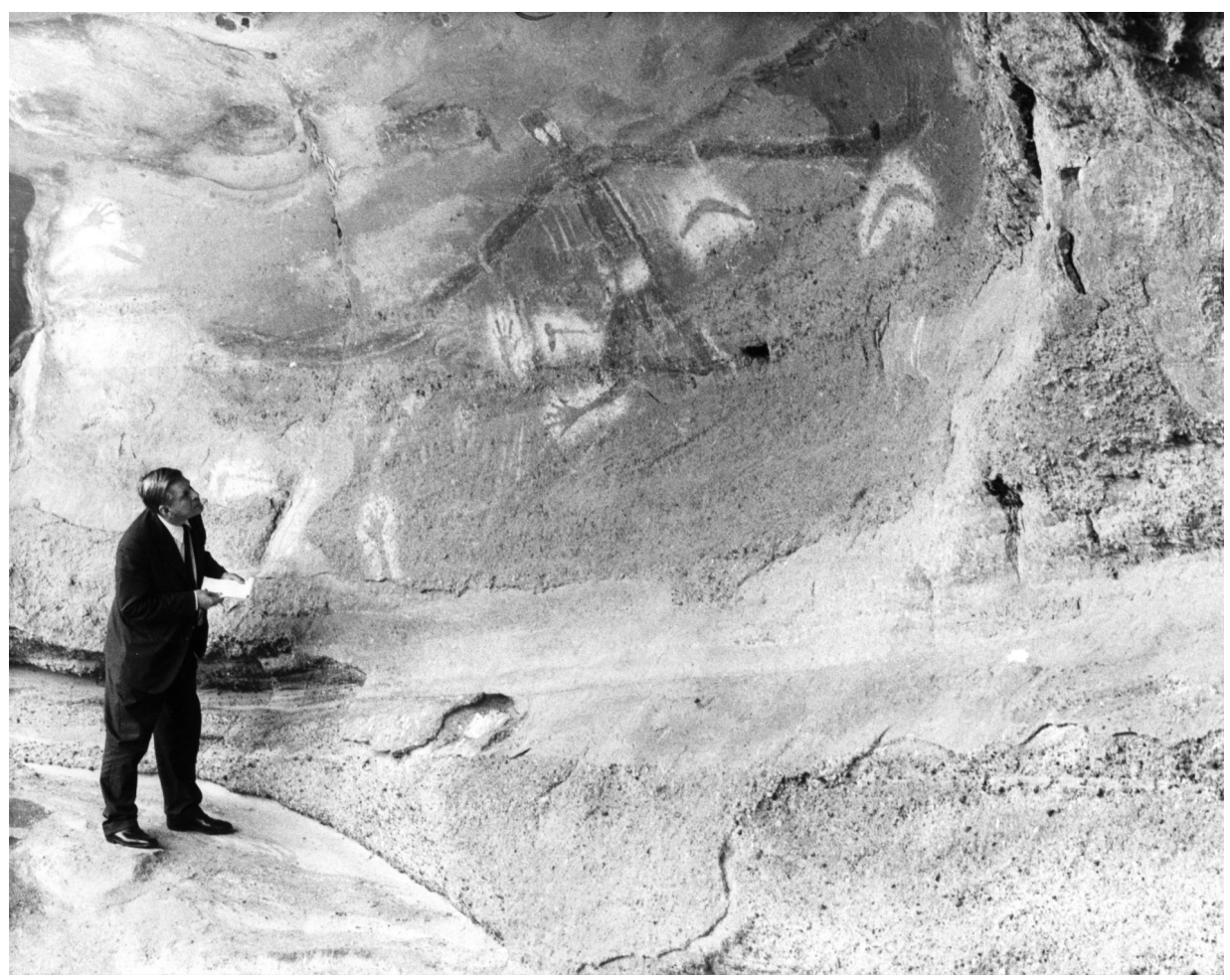

Percy Haslam takes notes at the Baime shelter at Broke near Newcastle.

Source: Courtesy of Auchmuty Library, University of Newcastle.

The Haslam Collection is housed at the University of Newcastle's Archives, Rare Books \& Special Collections Unit. The Haslam Collection itself is varied and diverse. It contains collections of Aboriginal tools, weapons and utensils, photographs, written studies of language, history, culture and personal reflections and memoirs across decades of work. In originally conducting work at the archives I acknowledge the assistance of both Gionni Di Gravio (who compiled a wonderful guide to the Haslam and other collections relating to Aboriginal History and Culture on the University of Newcastle Awaba website) and former archivist Denis Rowe. My archival work at the time was richly complemented by several key figures both Indigenous and non-Indigenous who knew Haslam well and consented to being interviewed.

Outside of Newcastle and the Hunter Valley both the man and his work remain virtually unknown. Some outsiders have suggested this may in part be due to Haslam himself, 'who was mysterious and secretive about his work'. ${ }^{1}$ As a journalist and a backyard scholar Haslam had operated throughout most of

1 Assessment comment on ARC application, ARC (2001) Indigenous Research Development Scheme, 'The Life's Work of Percy Haslam - Linguistic, Cultural and Historical Study of the Awabakal'. 
his life completely outside and disconnected from the academic arena. There are unquestionably elements of the romanticised Aboriginal 'Noble Savage' embedded in Haslam's work. He was a product of his time and was brought up on a staple diet of adventures in the wilds, through magazines and annuals like Boys Own, Lone-Hand, Gem and Magnet. Nevertheless his work and studies provides invaluable insight of the Awabakal people. From the latter part of the nineteenth century through to the 1960s a swath of professional and amateur anthropologists stampeded across the continent to study, dissect and analyse every conceivable Western viewpoint of Aboriginal cultural life - before the inevitable 'dying race' theory rung down the curtain on the last link on what was described as Stone-Age man. Martin Nakata in his groundbreaking study of the Haddon expedition in the Torres Strait has established a platform warning of the negative deficiencies in these studies yet recognising that they now provide a platform where Indigenous scholars can study, unpack and rework these materials to advantage from an Indigenous standpoint. ${ }^{2}$

The Awabakal through the work and efforts of missionary Reverend LE Threlkeld are one of the few south-eastern Aboriginal groups to be closely documented in the nineteenth century in regard to language, history and culture. Haslam's work in the twentieth century can be utilised to complement the much betterknown earlier nineteenth century works of Threlkeld, and throw new light on the evolving institutions and perceptions of the local Aboriginal people of Newcastle and its surrounds. The final verdict on Haslam and his work remain like the man still something of a mystery and contradiction. As we are now aware the missionary Lancelot Threlkeld and therefore Biraban as his informant never used the word Awabakal or Awaba in any form to describe the local Aboriginal people or its language. It was John Fraser some 60 years later who acknowledged that he invented the terms when editing Threlkeld's work for his publication An Australian language as spoken by the Awabakal, the people of Awaba or Lake Macquarie. ${ }^{3}$ In that context clearly Haslam was basing his knowledge on Fraser's inventions and not the original works of Threlkeld. However, Haslam himself recorded that by the early decades of the twentieth century the remnants of the traditional people had also begun referring to themselves as the Awabakal, which continues to this day.

Haslam's insight as a journalist and his concern for historical truth and objectivity were central to his working ethic. He himself attested that

As an experienced journalist, I was trained in the tradition that valid reporting, as is required of a journalist to inform the public by his written word, is "recording history on the wing." This does not mean that in the rush, which is so much part of daily newspaper, life should force the journalist to ignore the need to challenge and check. History, as much as

2 Nakata 2007: 195.

3 Powell 2011: 34-35; Keary 2009: 117; Lissarague 2006: 12-14. 
possible, must be what the writer believes to be the truth, stated simply and without distortion - the latter fault can easily stem from slovenly attitudes or inexperience; and of course, lack of knowledge. ${ }^{4}$

Percy Haslam was born in Newcastle, the son of Percy (Sen) and Clarice Haslam. Percy (Sen) had been badly wounded in World War One and his injuries impaired his working opportunities. Percy Haslam's grandfather had migrated from Britain in the 1840s, and his maternal grandfather Thomas Denny came to Newcastle from Victoria. Thomas Denny began working with the Newcastle Morning Herald in the 1880s and served the newspaper for over 50 years. He established what was to become a long lasting family tradition with the newspaper. Percy Haslam followed in his grandfather's footsteps and began work with the newspaper in 1933; he continued to work for the Herald for the next 44 years. A great uncle, Jos Hasslame (original spelling) was at Derrigaba (now Wickham an inner suburb of Newcastle) working at Farnham's the machinist shop in the 1830s. Jos Hasslame was forced to change his name to avoid the attention of the authorities, since he had links back in England with the Chartists, 'the first independent working-class movement in the world' ${ }^{5}$

Percy Haslam's other grandfather, Benjamin Haslam, came to Newcastle from Victoria as a small boy in 1852. The Haslams had a long-standing association with the railway. Benjamin Haslam was the second night officer appointed to Newcastle Railway Station. He had joined the railway in about 1870 going on to become the first station master appointed at Glen Innes and died there as a young man. His upbringing and family background instilled in Percy Haslam a very strong sense of family, work ethic and standing up for the underdog.

Percy Haslam's association and interest with Aboriginal people, culture and history stretches back to the first decades of the twentieth century. Haslam's uncle had an established friendship with Aboriginal people living in the bush. Percy recalled visits to Lake Macquarie, Toronto and Belmont in about 1917 where his 'first teachers were people of tribal tradition when he was about 8 years old'. People like Berntee, Gommera and Yee-oekarlah accompanied him on bush trips south of Swansea, Cooranbong, Martinsville and Mandalong. He was taught the language, and claimed to have been 'put through' Awabakal ceremonies when he was about 12 years of age and given the name Pip-peeta (little Hawk). ${ }^{6}$ He was the only member of the family to develop an insatiable appetite for Aboriginal culture and history. The knowledge and bush hunting skills Percy had learned from his Aboriginal teachers as a young boy proved invaluable during the years of the Depression. He recounted he was able to help his family, by supplementing their food supplies; 'they were able to eat a lot of duck'. ${ }^{7}$ Haslam acknowledged the gifts of 'people who were so kind and painstaking to teach ... what they believed to be true from personal experience

4 Haslam Collection, Archives, Auchmuty Library, University of Newcastle, see <http:/ / libguides. newcastle.edu.au/content.php?pid=70104\&sid=532113>, (accessed 16 September 2013).

5 Briggs 1983: 198.

6 Haslam 1988: 11-14.

7 Haslam 1988: 11-14. 
and oral tradition' ${ }^{8}$ Haslam reflected that when he was about 13, the Aboriginal people he knew had seemingly disappeared overnight. They were forced to move because of commercial interests in their land; the Forestry Commission had begun moving into their areas to meet large timber orders from New Zealand and South Africa to make piles and railway sleepers.

Haslam had originally been encouraged to pursue studies to become a doctor: as his brother put it, 'Perc had done 12 months medical'. ${ }^{9}$ In some respects he was favoured over the other family members, who look back with humour on those times. His mother would send his young brother Ben to the local shop and butcher to get 'the best salmon and asparagus tips for Perc and I remember that he would make me take it back if it wasn't up to scratch'.$^{10}$ Despite these family sacrifices to support his studies, the combined pressure of the Depression and his father's illness was too much for the family to bear. Against his family's pleading, Haslam abandoned his dream and took work at the Newcastle Morning Herald to ease the financial strain. Haslam joined the Newcastle newspaper then largely owned by the local Wansey and Berkeley families in 1933, and his first articles appeared soon after.

Ben Haslam related an anecdote about his brother Percy's career elevation and self-opinionated personality causing some tension within the family:

The place we lived in at Wickham was no mansion. There were eight in the family and I remember one time we had an uncle in the back room staying. Mum was a bit volatile at the time and had an argument with Percy because he liked to be king of the castle. She grabbed his typewriter and threw it straight out the back door and it hit the uncle in the face as he was coming up the steps. ${ }^{11}$

Throughout the 1930s and 1940s Haslam wrote a weekly column on friendly societies, featuring historical material. He had access to the early minute books and documents relating to Foresters, Druids and Oddfellows and so forth. He became official historian for the now defunct Newcastle Friendly Societies Association. Much of this historical material was re-published in lodge magazines. He was the only person to undertake friendly society research in the region. He still held the first minute book of the Court Hunter of the Ancient Order of Foresters (later absorbed by Manchester Unity Oddfellows). This was the first Ancient Order of Foresters lodge in the Newcastle district. He became the Newcastle Herald's industrial and political roundsman and later became an associate editor. His political coverage included trips to New Zealand to cover the election of Michael Savage as the first New Zealand Labor Prime Minister in 1937 and also a visit to the United States during the 1940s.

8 Haslam Collection, Archives, Auchmuty Library, University of Newcastle.

9 Interview with Harold 'Doc' Haslam, Newcastle, 27 November 2000, John Maynard personal collection.

10 Interview with Ben Haslam, Newcastle, 25 July 2001, John Maynard personal collection.

11 Interview with Ben Haslam, Newcastle, 25 July 2001, John Maynard personal collection. 
Ben Haslam felt at the time, Percy was 'our star boarder or the one who was earning the most money. He modified short hand to suit himself and he was the only one who could read it. He used to have a lot of political contacts'. ${ }^{12}$ Percy Haslam to put it mildly was a bit eccentric, he walked everywhere, never caught the public transport. His brother Ben said, during a conversation he would sit back in a chair, with his head back deep in thought with his eyes closed. He would often pass his family members on the street not having recognised them coming towards him. ${ }^{13}$

Wickham was a tough neighbourhood during Percy's young life and his brother Ben stated that the 'trouble for Perc was that he still remembered his roots and he might have got offside with a lot of people on the classier side'. ${ }^{14}$ The Haslam's moved to Hamilton another Newcastle suburb just before the outbreak of World War Two. This marked another Aboriginal connection for the family as the house backed onto the famous Tom Maguire boxing gymnasium and during those years it was home to the legendary 'Fighting Sands' brothers. Ben Haslam recalled 'a cousin of ours hung around with Dave Sands and he would bring him into our place' ${ }^{15}$ Percy now established as a top rank journalist had married and was the father of two young children. But he had to endure tragedy and hardship, his wife, a sister at a local hospital died in her early thirties 'of a brain tumour and he was left to raise a very young girl and boy, and mum helped him'. ${ }^{16}$

Throughout his working life his interest in Aboriginal culture and history never waned, and he read and travelled widely throughout the district in search of stories and mementoes. He was very well known and respected throughout the area particularly through his political columns. In about 1960 he was approached by the late Mr DR Blakemore then President of the Lake Macquarie Historical Society. Blakemore wanted Haslam to assist him in a research project concerning the Awabakal, supposedly using the linguistic writings of missionary Reverend LE Threlkeld as its base. Mr Blakemore was the first principal of Booragul High School and he was a scholar in languages. It was their intention to combine the language research with a significant cultural and historical study. They began by interviewing old residents aged 90 to 100, particularly in the Swansea, Martinsville and Cooranbong areas. Swansea was chosen because there was a rich field to exploit locally. Historians had overlooked the fact that the last pocket of tribal Awabakal people, though partly absorbed in urban life to some extent, had lived on there. Haslam and Blakemore spoke to elderly people who as children either spoke Awabakal or heard it spoken. They ascertained also that from the 1870s to 1880s white people freely spoke Awabakal as well, in Swansea, Pelican, and possibly Belmont South. The pair spent years checking and rechecking the language and traditional stories and other information handed down from generation to generation.

12 Interview with Ben Haslam, Newcastle, 25 July 2001, John Maynard personal collection.

13 Interview with Ben Haslam, Newcastle, 25 July 2001, John Maynard personal collection.

14 Interview with Ben Haslam, Newcastle, 25 July 2001, John Maynard personal collection.

15 Interview with Ben Haslam, Newcastle, 25 July 2001, John Maynard personal collection.

16 Interview with Ben Haslam, Newcastle, 25 July 2001, John Maynard personal collection. 
Blakemore died suddenly in the early 1970s, but Percy Haslam continued on with the project in a dual capacity. For the next 17 years of his life Percy Haslam continued his personal quest in search of knowledge of the local Awabakal people. His emergence as a scholar in his own right in the mid 1970s coincided with the resurgence of a vibrant, proactive Newcastle Aboriginal community. In the wake of the 1967 Referendum and the inspirational Aboriginal Tent Embassy in 1972 Aboriginal people were fuelled with hope and pride in the future, and demands for Self Determination and Land Rights became the vocal catch cries. Newcastle had always been a viable alternative to the oppressive paternalistic government policies of the past including segregation on reserves. The heavy industries based in Newcastle ignored racism and anyone walking through the gate at BHP with his or her hand up got a job. ${ }^{17}$ The impact of the 1972 Aboriginal family voluntary resettlement scheme saw hundreds of Aboriginal people move to urban centres like Newcastle, 'reaching out for a better future for their children' ${ }^{18}$ Aboriginal people took this opportunity with relish and many important Aboriginal community organisations based in Newcastle were a direct result of this exciting period.

It was in this environment that Percy Haslam rose to prominence amongst the vibrant politically charged and changing Aboriginal community of Newcastle. The Newcastle Awabakal Co-op was one of the major achievements of the time period. It was established to provide empowerment to the Aboriginal communities of the Hunter through the delivery of health and social services. John Heath recalls

I got involved with what was then the beginning of the Awabakal Co-op and I became a member of the Board of Directors and the Treasurer of that organisation. We were fighting for government funds at that time... Because of his interest in Koori things particularly language he (Percy) came into meet some of the local community. ${ }^{19}$

John Heath, one of the Co-op's founding members, recalled that Victoria Mathews, the Co-op secretary, pulled him aside and said 'this old whitefella came in and he speaks the lingo and wants to meet some more of the mob'. ${ }^{20}$ John Heath then arranged to meet him and reflected that 'when talking with other people Perc had his own way of expressing himself and some people might think it was pompous. He was very proud of the fact that he had some understanding of the Awabakal language'.$^{21}$ John Heath confessed he was no linguist but arranged for some Gumbaynngir elders who were speakers of their language to meet Haslam. They stated that they were impressed and assured with the

17 Maynard 2001: 258.

18 McLeod 1982: 1.

19 Interview with John Heath, Newcastle, 24 July 2001, John Maynard personal collection.

20 Interview with John Heath, Newcastle, 24 July 2001, John Maynard personal collection.

21 Interview with John Heath, Newcastle, 24 July 2001, John Maynard personal collection. 
way that he could speak the language, his pronunciation and diction and so forth. So I accepted that... So for me he was a genuine kind of article... He did have a lot of knowledge that a lot of people didn't have. To talk with him about those things and try and change his point of view was a real challenge. He could be really stubborn at times. ${ }^{22}$

Haslam became actively involved with the Awabakal Co-op and over the course of ten years he worked with a lot of people including 'Tommy Sales from the Darkinjung people on the Central Coast and Kenny McBryde who was a Bundjalung man who lived at Toronto, Jimmy Wright was also involved and a young Ray Kelly did some work at that time' ${ }^{23}$

On his retirement from the Newcastle Morning Herald in 1977 Haslam was elected as Convocation Research Fellow at the University of Newcastle to study the local Awabakal language and culture. Haslam with some humility reflected on his move to academic life.

I present myself as a recorder of history based on a lifetime of old time traditions of journalism, heavily affected by "grass roots" attitudes. I can quite appreciate my position intruding, as it were, into the hallowed halls of academia. I shall remain ever grateful to the "Newcastle Herald" and convocation of Newcastle University for the unique experience of being the convocation's first visiting scholar, to be attached to the English Department for six months, to continue and complete my research into Aboriginal history of the Hunter region and some coastal areas...

I felt somewhat timid at first (but can this really be true of a journalist who worked so long in a place like Newcastle with its own special rugged political and industrial rules), but the warmth and help of academics from the Vice-chancellor (Dr Don George) downwards, removed any sense of inferiority, real or imagined, to become absorbed into that atmosphere peculiar to a university campus. ${ }^{24}$

Emeritus Professor John Ramsland the former Dean of the Faculty of Arts \& Social Sciences at the University of Newcastle felt that during this period the was the University's most eminent scholar' ${ }^{25}$ Dr Bernie Curran recalls Percy Haslam's arrival:

he came into the Classics Department because he was working on Threlkeld's grammar. I was just fascinated by the language and culture which Perc was trying to retrieve. He became very much involved with 2 NUR... and tapes were made of his programs I know that for sure. ${ }^{26}$

22 Interview with John Heath, Newcastle, 24 July 2001, John Maynard personal collection.

23 Interview with John Heath, Newcastle, 24 July 2001, John Maynard personal collection.

24 Haslam Collection, Archives, Auchmuty Library, University of Newcastle.

25 Conversation with John Ramsland, 2001, University of Newcastle.

26 Interview with Dr Bernie Curran, Newcastle, 26 July 2001, John Maynard personal collection. 
In 1981 Haslam left Newcastle for a brief visit to the United Kingdom primarily to research manuscripts relating to primary settlement in the Hunter Valley and Port Stephens. He visited Cambridge University with the late Emeritus Professor Godfrey Tanner, at the time the Dean of the Faculty of Arts, at the University of Newcastle, and a Fellow of St John's College, Cambridge who introduced him at Cambridge. Haslam and Godfrey Tanner formed a very close friendship:

Well I was interested to meet Percy Haslam when he wanted to come to see me about the fact of his great concern with the Awabakal language. I of course had studied when in Cambridge Sanskrit under Sir Harold Bailey as well as the Latin and Greek domain of my degree. Percy a retired journalist had worked for years understanding this language of the Awabakal because as a boy he had met a few of the surviving speakers and he got to know them quite well and they became family friends as it were and he was able to understand a lot about pronunciation and the relationship of the language. ${ }^{27}$

Haslam also visited archives at the London Museum and the Congregation World Church Council because of the records held there of early missionary efforts in New South Wales. He was particularly interested in discovering new material relating to Reverend LE Threlkeld and the mission he had established at Lake Macquarie.

I took Percy in to see what records we had in Cambridge... We had a very good time in the Missionary Society in London they showed us all the papers on the matter... he found out a great deal about the position confronting Threlkeld... ${ }^{28}$

At the time Percy Haslam said 'Threlkeld is now emerging as a very important person in primary history on Aborigines in colonial times. His work on language and culture in our region are as good as any ever recorded, having regard for the times in which he lived and limited facilities available to record history' ${ }^{29}$ Aside from Threlkeld, Haslam was also interested in republishing the diary of Isabella Parry wife of famous Arctic explorer William Edward Parry. Parry was for a time in charge of the Australian Agricultural Company at Port Stephens and his wife kept a diary complete with illustrations. Unfortunately Haslam and Godfrey Tanner were unable on that visit to meet with Ann Parry the great great grand daughter of Lady Parry. But Godfrey Tanner later met with her and had lunch at his London club. Parry at the time was the librarian at the House of Commons and had written the book Parry of the Arctic. She expressed that she was very happy to give permission for Percy Haslam to reproduce her great great grandmother's diaries and illustrations. However, unfortunately, these diaries have never been published.

27 Interview with Professor Godfrey Tanner, Newcastle, 25 July 2001, John Maynard personal collection.

28 Interview with Professor Godfrey Tanner, Newcastle, 25 July 2001, John Maynard personal collection.

29 Haslam Collection, Archives, Auchmuty Library, University of Newcastle. 
On Haslam's return to Australia the Institute of Aboriginal Development, ${ }^{30}$ with headquarters in the Northern Territory invited Percy Haslam to join a steering committee to form the first Aboriginal Languages Association and to address a workshop at Alice Springs.

Percy of course was also very determined not just merely seeing Aboriginal artists getting a vogue which some of them very much deserved but he wanted to show that the traditional tribal art was of a very high artistic value and also encapsulated the culture. ${ }^{31}$

Clearly Haslam's profile within the region was on the rise with increasing recognition of his work and demands on his time and input. During this time he was appointed official historian for the Central Aboriginal Sites Committee covering the area from the Hawkesbury to the upper Hunter and Taree. Haslam had a great love and understanding of the bush environs of Newcastle and the Hunter Valley. He lamented the damage modern society inflicted upon the

natural habitat of the food hunt - the waterways, bush and mountain... what a contrast with the immediate environs! Ever so much presence there of European culture: cultivated farmlands, habitations of brick and mortar, and tar-sealed roads. And of course the pollution that flows from so many sources of machine operations: noise and contaminated air. ${ }^{32}$

Haslam over the years had gained great knowledge of the Hunter Valley and Watagan Mountains in relation to Aboriginal sites of significance. As John Heath explained:

He made full use of the fact that he was a non-Indigenous person and made acquaintances with a lot of property owners and that was also of benefit. In the late 1970s there was a genuine concern among the non-Indigenous community with our cries for land rights. There was a worry that a blackfella was going to come up and claim the farm. So a lot of white people did not openly acknowledge these sites... Perc was often a conduit with the non-Indigenous community. We took him into our confidence... and we worked alongside him to gain some of that knowledge. ${ }^{33}$

30 The Institute for Aboriginal Development Incorporated (IAD) was established by the Uniting Church in 1969 to assist community development for Aboriginal people and provide crosscultural education between Aboriginal and non-Aboriginal society.

31 Interview with Professor Godfrey Tanner, Newcastle, 25 July 2001, John Maynard personal collection.

32 Haslam 1978b: 2.

33 Interview with John Heath, Newcastle, 24 July 2001, John Maynard personal collection. 


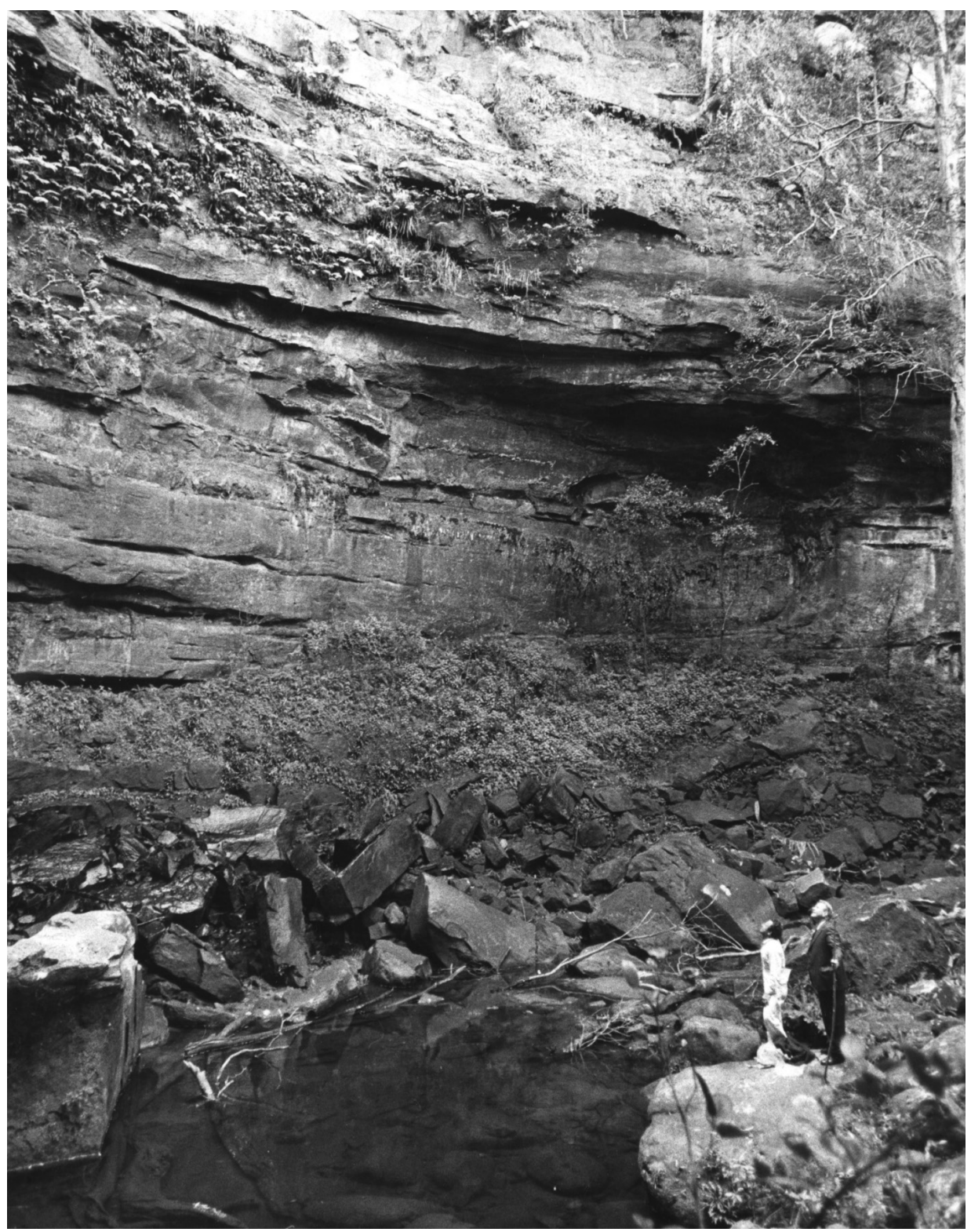

Haslam and friend, Browns waterfall, Watagans near Newcastle.

Source: Courtesy of Auchmuty Library, University of Newcastle. 
The Aboriginal community became actively involved in opposing mining and land development that threatened Aboriginal sites of significance and they pushed for Aboriginal involvement with environmental impact studies. Haslam's political contacts and knowledge also proved invaluable 'Perc had a close relationship with one of the ministers at the time and we used that to put pressure on the departments'. Stopping a proposed dam 'was one of the really big wins for us at the time. Percy spent time in the field with us and the team comprised Uncle Bert Marr, Zac Martin and Uncle Guboo Ted Thomas from the South Coast. So there were some terrific times' ${ }^{34}$ The camaraderie and close connections of this group manifest clearly in one very funny incident recalled by John Heath:

Uncle Zac was from Cherbourg. He was a tricky bugger and liked to take a charge [have a drink]. Perc took a bottle of whisky up to the camp in case someone got bitten by a snake... It didn't take long for Uncle Zac to figure out the bottle was there. Old Percy was a tricky fella too, so he had the bottle lying on its side up on a makeshift cupboard they had set up in the tent. He had tried to hide the bottle so Zac wouldn't know it was there. He didn't want to be digging it out each day to check to see it was still full, so he had the neck of the bottle poking out from behind some things so that he could see that there was liquid in it... It didn't take uncle Zac long to get into it. Zac was changing the angle of the bottle each day slightly as he was reducing it. Finally when old Percy realised the bottle was on a ninety-degree angle to that he originally placed it. Percy said 'Zac must have been bitten on the lips by a snake'. ${ }^{35}$

One of Haslam's colleagues from the University, Dr Bernie Currans, mused on his significant impact in drawing attention to the importance of the local Aboriginal culture and language.

Where did he develop this fascination with the Aboriginal thing? Why did it become such a cause? He was one of the earliest ones to really take on that flag, in that context where there was a certain amount of skepticism about how much you could really find out, and how much knowledge you could actually gain. I think his biggest contribution was he unearthed so much through his interviews, and through his desire to keep it alive. He added a lot of colour. Perc became our kind of Guru if you like of Aboriginal culture. ${ }^{36}$

John Heath also recognised the significance of Haslam's foresight about maintaining Aboriginal culture: 'He really did have a strong desire to see what he saw as Indigenous culture preserved and maintained as a living rather than museum species'. ${ }^{37}$ Haslam in many instances was a man well ahead of his time especially in the recognition of Aboriginal history and the political rights

34 Interview with John Heath, Newcastle, 24 July 2001, John Maynard personal collection.

35 Interview with John Heath, Newcastle, 24 July 2001, John Maynard personal collection.

36 Interview with Dr Bernie Curran, Newcastle, 26 July 2001, John Maynard personal collection.

37 Interview with Dr Bernie Curran, Newcastle, 26 July 2001, John Maynard personal collection. 
of Aboriginal Australia. Writing on the impact of European invasion in New South Wales he sadly reflected that in a 'relatively quick time many coastal tribes in NSW suffered extinction (one wonders whether the term "extermination" would be more appropriate) $)^{\prime} \cdot{ }^{38}$ He also challenged the prevailing view about the role of Aboriginal women in traditional society stating 'there had been too much denigration of Aboriginal women; so much was their history distorted that most Europeans had for generations gained a false view of how important a part Aboriginal women played within their own society'.$^{39}$

He was instrumental and a driving force behind an Awabakal language revitalisation project, which began at Gateshead High School in 1986. The University of Newcastle supported the project, which sought to restore the Awabakal mother tongue to persons of Aboriginal descent residing in the Hunter.

We set the seeds of an Awabakal language program. Because Perc was white and an older person he wasn't a good teacher in the sense for the young kids so I became a teacher alongside him. My involvement was to learn the lesson the week before the kids. So together we started an elementary language program. At least we were preserving aspects of the language. We often had fifteen or twenty people mainly kids but we had older people as well. ${ }^{40}$

A link to this project was a weekly program of language lessons conducted by Haslam on radio station 2NUR called 'Awabakal Voices'. Haslam said: 'It would be wonderful if by 1988 we could return to Aborigines something European society took away from them, this was a vital facet of their identity, their mother tongue' ${ }^{41}$ Clearly Haslam's record and standing during these years was extremely high within the Newcastle area. He was a vocal campaigner on the importance of cultural knowledge still held within Aboriginal communities and that whilst 'due consideration must be given to what had already been recorded, notwithstanding some areas of conflict, grass roots research involving people still able to recall some of the vital history and culture of a tribe had an urgent priority'. ${ }^{42}$ He certainly practised what he preached:

He wrote a lot of the mythology especially around Lake Macquarie when he was writer in residence. What he did to resurrect the knowledge of Threlkeld. Threlkeld got absolutely minimal interest from people. So that was the most important thing he did. He made us aware... He wanted to bring the culture alive. He was trying to give memory to certain geographical features and show you the stories. ${ }^{43}$

38 Haslam Collection, Archives, Auchmuty Library, University of Newcastle.

39 Haslam 1984: 11-12.

40 Interview with John Heath, Newcastle, 24 July 2001, John Maynard personal collection.

41 Haslam Collection, Archives, Auchmuty Library, University of Newcastle.

42 Haslam 1978a: 4-5.

43 Interview with Dr Bernie Curran, Newcastle, 26 July 2001, John Maynard personal collection. 
Indigenous academic Deirdre Heitmeyer a longtime employee at Wollotuka Institute at the University of Newcastle reflected:

I only ever saw him as someone who knew a lot about the local Aboriginal area. I found him to be so knowledgeable about the concrete things... He was a great speaker and very charismatic. He educated a lot of nonIndigenous people, and Newcastle with its so-called tolerance, well a lot more tolerance than a hell of a lot of other places and Percy had a lot to do with that by being different. ${ }^{44}$

Haslam took his language and cultural teaching programs to Aboriginal inmates at Cessnock gaol. One Aboriginal man at Cessnock related that it gave him a sense of pride and understanding he had not had before, 'the things I am learning here will mean that I won't be back' ${ }^{45}$ As a result of the project at Cessnock he was approached by the Aborigines Prisoners Progressive Committee at Long Bay to visit them and conduct monthly visits to conduct Aboriginal history, language and cultural lectures. 'I remember his work in the gaols as well, he did a hell of a lot of work with the prisoners out there he was tireless in that ${ }^{\prime}{ }^{46}$ Sadly Percy Haslam died suddenly on 17 September 1987 aged 75 and remains as a great loss to the local Aboriginal and wider Newcastle community. Deirdre Heitmeyer went to a meeting where Percy was due to talk at Maitland on the evening of his death. When she walked in 'everyone had tears in their eyes, everybody felt the amount of loss at that time, both Aboriginal and non-Aboriginal. What I remember most, that sense of "oh my god" all that knowledge is gone'. ${ }^{47}$

Heitmeyer's sense of loss was compounded by the fact that straight after Haslam's sudden death, his unfinished manuscript on Lady Parry's journal, as well as his recordings and radio programs went missing. It appeared that a large slice of Haslam's work had simply disappeared. As late as 2000, Haslam's brother 'Doc', still worried about what had happened to his research:

Why didn't they let someone who knew the value of the stuff go through it? Some bloody Sheila was supposed to have taken a lot of the stuff. I don't know who that was. She was printing a book he had started. ${ }^{48}$

The Haslam Collection at the University of Newcastle does not contain these missing manuscripts or recordings. However, a recent conversation with his daughter Janis has solved the mystery of the manuscripts. Shortly after Haslam's death in 1987, an unidentified man had gained access to Percy's flat before the family had gone there, and removed some items. However, Haslam's son, Ian confronted the individual and took the items back, where he has kept them in a safe, out of the public domain, ever since. Sadly, the greatest tragedy is that

44 Interview with Deirdre Heitmeyer, Newcastle, 22 July 2001, John Maynard personal collection.

45 Haslam Collection, Archives, Auchmuty Library, University of Newcastle.

46 Interview with Deirdre Heitmeyer, Newcastle, 22 July 2001, John Maynard personal collection.

47 Interview with Deirdre Heitmeyer, Newcastle, 22 July 2001, John Maynard personal collection.

48 Interview with Harold 'Doc' Haslam, Newcastle, 27 November 2000, John Maynard personal collection. 
Haslam's work, the product of his obsession and passion for revitalising and maintaining local Aboriginal history, language and culture, has not been widely disseminated, and thus not left the mark it deserved.

In conclusion, the often missed significance of amateur historians/ethnographers like Haslam, who have developed passionate and longstanding connections with local Aboriginal communities, often long before academic historians did, and created important archives not only used by other scholars, is that they also, and more importantly, provide Aboriginal communities with a rich resource that assists their directives of language revival and maintaining cultural and historical knowledge. This article highlights the need for such figures to be recognised, for in doing so historians can also recognise the agency of local Aboriginal communities who engaged with figures like Haslam in their formative years, offering their knowledge and friendship, and instilling a life-long interest in Aboriginal culture and language. Figures like Haslam, can in turn also be seen as important conduits of this knowledge, for he was then able to pass on all he had learned to later Aboriginal generations.

\section{References}

\section{Primary Source}

Haslam Collection, Archives, Auchmuty Library, University of Newcastle.

\section{Newspaper and magazine}

The Newcastle Morning Herald

University of Newcastle News

\section{Secondary Sources}

Assessment comment on ARC application, ARC (2001) Indigenous Research Development Scheme, 'The Life's Work of Percy Haslam - Linguistic, Cultural and Historical Study of the Awabakal'.

Briggs, A 1983, A Social History of England, Weidenfeld and Nicholson, London.

Faculty of Education and Arts 2013, 'Awaba homepage', University of Newcastle, <http:/ / www.newcastle.edu.au/school/hss/research/publications / awaba/>, (accessed 16 September 2013).

Haslam, P 1978a, 'History of Aborigines', University of Newcastle News, March: 4-5. 
- 1978b, 'Preserving the past - natures way', Hunter District Water Board Journal (Spring): 2-5.

- 1984, 'A woman's place in Aboriginal society', Newcastle and Hunter District Historical Society Journal and Proceedings, March: 11-12.

- 1988, 'Friend to the Awabakal', in Voices from a Vanishing Australia: Recollections of the Way Things Used To Be, ABC Books, Sydney.

Keary, A 2009, 'Christianity, colonialism, and cross-cultural translation: Lancelot Threlkeld, Biraban, and the Awabakal', Aboriginal History 33: 117-155.

Lissarague, A 2006, A Salvage Grammar and Wordlist of the Language from the Hunter River and Lake Macquarie, Muurrbay Language and Culture Centre, Nambucca Heads, New South Wales.

McLeod, I 1982, Shade and Shelter - The Story of Aboriginal Family Resettlement, Jacaranda Press, Sydney.

Maynard, J 2001, 'Muloobinbah (Newcastle) an Aboriginal industrial presence: past and present', Journal of the Royal Australian Historical Society 87(2): 248266.

Powell, MW and R Hesline 2011, 'Making tribes? Constructing Aboriginal tribal entities in Sydney and coastal NSW from the early colonial period to the present', Journal of the Royal Australian Historical Society 96(2): 115-148.

Tanner, Professor Godfrey 1984, conferring of degrees address, University of Newcastle. 